\title{
The Culturalization Process of Learners in the Polish-German Borderland
}

\begin{abstract}
The issues explored in the article concern experiencing acculturation stress by children inhabiting Gubin (on the Polish-German borderland) whose parents decided to educate and fulfill school duties in the German cultural environment in the neighbouring Guben. It was assumed that methodical education in German school of Polish children who live with their parents in their homeland: (a) contributes to the children's applying different culturalization strategies in different areas of life - these differences are visible mostly in the public and private sphere and they change with growing up; (b) becomes the source of permanent and/or recurrent enculturation stress, which children at primary education age are not prepared to manage in the psycho-physical (individual) and social dimension as they lack family support and the support from the receiving environment (culture).

What became the basis for the undertaken discussion were the results of some studies conducted in the Polish-German borderland in 2004. They concerned the axiological preferences of I-III class children living in culturally diversified environments as well as some new phenomena, not observed in other regions. They encouraged the author of this study to provide a broader view upon the issues of the culturalization process and to repeat the studies in 2007 and 2017 in order to capture the relative dynamics of this phenomenon.
\end{abstract}

\section{Keywords:}

Polish-German borderland, cultural identity, national identifications, culturalization strategies, longitudinal studies 


\section{INTRODUCTION}

The undertaken discussion pertains to the issues of acculturation stress experienced by the children living in Gubin (in the Polish-German borderland), whose parents decided to educate and fulfil their children's school duty in the German cultural environment in the neighbouring Guben.

My stay in the Polish-German borderland in 2004, due to the studies on axiological preferences of I-III class children inhabiting culturally differentiated environments (Ogrodzka-Mazur, 2007), as well as the observation of new phenomena appearing in other investigated areas inclined me to view the issues of acculturation in a broader perspective and to repeat the research in 2007 (Ogrodzka-Mazur, 2010, pp. 17-28) and 2017 in order to capture the dynamics of this process.

On the basis of the theoretical knowledge of the analysed phenomena, an assumption was also made that the systematic education in German school of Polish children living with their parents in their homeland contributes to: (a) their applying different culturalization strategies in various spheres of life - the differences are mostly noticed in the public (social) and private (family) sphere and the strategies change as children grow up; (b) the permanent and/or frequently recurring acculturation stress, for coping with which a child at early school age is not prepared in the psycho-physical (individual) and social dimension. Such a child usually lacks support from family and the receiving environment (culture).

\section{THEORETICAL AND METHODOLOGICAL ASSUMPTIONS}

The culturalization foundations of children and their parents have been specified in the context of Paweł Boski’s (1) cultural model of acquiring biculturalism, which takes into account the distinction of two levels in each cultural system - the symbolic and axiological (values and practices). Each cultural system also comprises the following components: (a) cultural knowledge, (b) language competences, (c) affective bonds, (d) feeling od unlikeness and difficulty, (e) bicultural identity (preservation and acquisition), (f) the own life situation and satisfaction with it (Boski, 2009, pp. 548-564). Referring to the suggested model in pedagogical analyses assumes the possibility of cultural transmission in the conditions of the intentional process of teaching and learning (e.g., in family, school, peer group, local environment) as well as the experience in social discourse of a particular country. Compared to traditional concepts of acculturation (Berry, 1994, pp. 211-215; Wysocka, 2003, pp. 74-79), this constitutes the most complex 
construct, which explores integration in four senses - as bilingual/bicultural competence, as "functional specialization", as a new quality which results from fused elements, and as psychological autonomy towards both original cultures (Boski, 2009, pp. 542-547).

The acculturation process and experiencing acculturation stress are also related to the individual's perception of the distance between the native and the receiving culture. In order to outline the changes occurring in this respect in the case of Polish children, Paweł Boski's theoretical standpoint was applied, represented by his (2) concept of cultural distance. It comprises the analysis of cultural distance from the point of view of criteria-related (knowledge of cultural symbols) and correlative (behaviour which reflects normative assumptions and values of a particular culture) identity attributes (Boski, 1992, pp. 86-108). The relations are presented in Table 1.

Table 1. Cultural Distance and Its Consequences for the Processes of Identity Changes

\begin{tabular}{|c|c|c|c|}
\hline \multirow{4}{*}{ 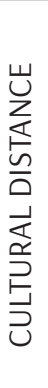 } & \multirow{3}{*}{ 岕 } & \multicolumn{2}{|c|}{ ATTRIBUTES } \\
\hline & & CRITERIA-RELATED & CORRELATIVE \\
\hline & & $\begin{array}{l}\text { The range of common symbols } \\
\text { Different sign of evaluation } \\
\text { Identity conflict }\end{array}$ & $\begin{array}{l}\text { Similarity of values, customs and } \\
\text { lifestyles } \\
\text { Easiness of acculturation }\end{array}$ \\
\hline & 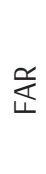 & $\begin{array}{l}\text { Strangeness, lack of a range of common } \\
\text { symbols } \\
\text { Neutrality, lack of conflict }\end{array}$ & $\begin{array}{l}\text { Discordant, contradictory values and } \\
\quad \text { social norms } \\
\text { Acculturation stress } \\
\text { Identity conflict }\end{array}$ \\
\hline
\end{tabular}

Source: Boski, 1992, p. 102.

The cultural distance developing in an individual and the resulting changes in identity might hinder the process of social identification and lead to biculturalism, the rejection of primary identity or the acquisition of, e.g., negative identity.

An important perspective in the search for rules which determine shaping the feeling of identity in the changing borderland conditions was offered by (3) the theory of identity behaviours, elaborated by Tadeusz Lewowicki. The theory enables both comprehensive and comparative capturing of the processes and phenomena taking place in borderlands. The identity fields distinguished by the author become significant determinants of identity behaviour patterns - the first field comprises historical vicissitudes and identification with a particular territory and social group; the second is marked by the unlikeness of culture, language, transmission of tradition and the knowledge of spiritual and material output of 
the society; the third - is associated with a special kind of historical genealogy and specific qualities of the groups and the stereotypes functioning within them; the fourth - concerns the industrial and economic condition and living standards of the group(s); the fifth - is associated with the needs, life aims and axiological preferences; and the sixth - takes into account the political, ideological, social and economic context (Lewowicki, 1995a, pp. 51-63, 1995b, pp. 13-26).

In the theoretical assumptions, (4) the theories of cross-group contact and mutual cross-group diversification derived from the hypothesis of contact were also referred to (Stephan \& Stephan, 1999, pp. 70-97; Hewstone, 1999, pp. 267-282). Concordantly with their broadened model (Figure 1), it has been assumed that the effects (C) of cross-group contact between the Polish children and their German peers and the teachers are a function (f) of the person (P), situation (S) and social context (SC): $C=f(P+S+S C)$.

Figure 1. Casual Model of the Hypothesis of Contact

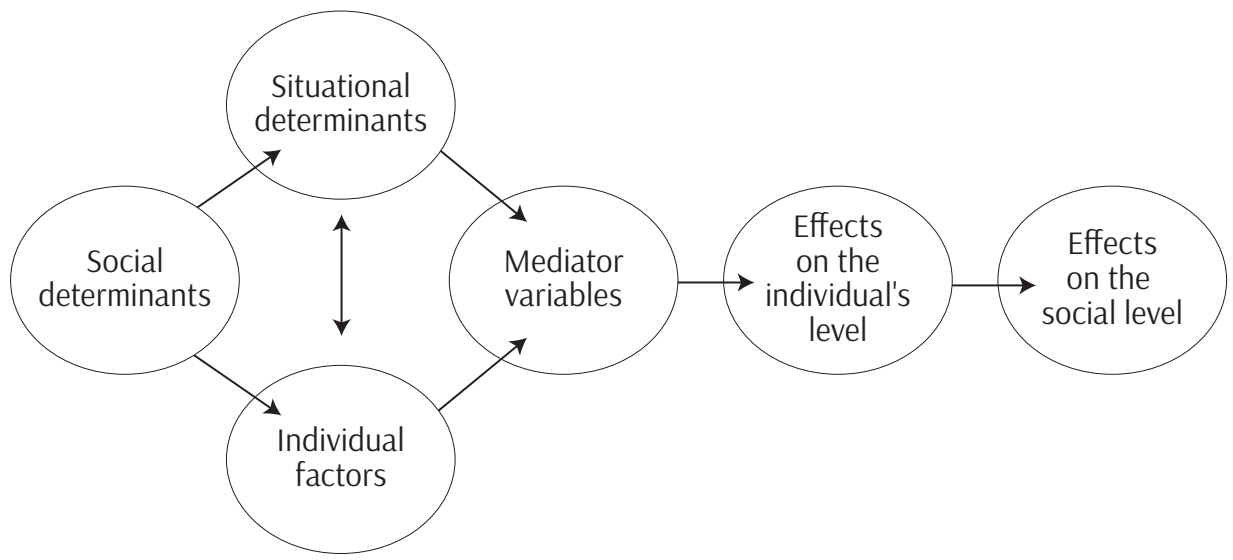

Source: Stephan \& Stephan, 1999, p. 80

Due to the social and cultural specificity of the Polish-German borderland, the distinguished constituents of the suggested model are the following:

- in the social context:

- group structure (children's age, sex, residence place, parents' nationality, religion),

- social and cultural determinants of the relationship between the groups in contact,

- present relations between the groups, 
- the course of acculturation and socialization processes in both groups;

- in the situational context:

- the environment in which the contact takes place,

- the character of the interaction,

- the composition of the group,

- $\quad$ tasks carried out by the participants;

- individual factors:

- demographic variables,

- personality traits,

- stereotypes, prejudice and other beliefs;

- mediator variables:

- cognitive processes,

- emotional processes,

- behavioural processes;

- effects on the individual's level:

- beliefs (stereotypes and prejudice in particular),

- emotional reactions,

- behaviour patterns;

- effects on the social level:

- changes of attitudes presented in public (especially in the case of stereotyping and prejudice),

- changes of social norms functioning in groups.

The significance and usefulness of the presented model in the conducted pedagogical studies can be specified, first of all, in the area of interactions between all factors with the specification of cause-result relations. Secondly, the model suggests the existence (within each category) of several variables which might affect each situation of group contact. Thirdly, the model indicates the factors which can be considered in the attempts to use the contact for improving cross-group relationships (Stephan \& Stephan, 1999, pp. 81-83).

Taking into account the applied theoretical assumptions, the methods of collecting and analyzing qualitative-quantitative data were used in the research, with particular focus on the specificity of individual studies on children. Special attention was drawn, in the basic methodological assumptions of these studies, not only to the researcher's empathic attitude to the examined subject (the child) but also to the aspects of research ethics, to the knowledge of the child's reflectiveness as an interview partner, and to methodological competences of researchers themselves (Köpp \& Lippitz, 2001, pp. 158-160). In the analysis of empirical materials, the 
reducing and developing way of data transformation was applied and the interpretative approach was followed in the analysis of the meaning of statements in the context of: understanding the examined people's thoughts, critical reasonable understanding and theoretical understanding (Kvale, 2004, pp. 213-231; Miles \& Huberman, 2000). In composing a complete picture of the phenomena, the phenomenological approach was used, which consisted in the transition from individual textural-structural relations of meanings and the nature of the respondents' experiences to the synthesis in the form of a universal description of cultural experiences which represent the group(s) as a whole (Moustakas, 2001, pp. 147-149).

In the newest research, the strategy of longitudinal comparisons was additionally used. It was based on the time criterion and was aimed at understanding the mechanisms of change and the behavior determinants of groups and particular individuals living in the same socio-economic and cultural time. This was achieved by applying survey studies with the use of the panel (repeatable) method, the assumption of which was carrying out - at least twice with a time interval - measurements of a certain number of people in regard to the same quality. They were aimed at capturing the dynamics of a particular phenomenon. They allow not only for presenting the inner dynamics of a change but also for seizing certain mechanisms which determine this change (Frankfort-Nachmias \& Nachmias, 2001, pp. 153-154; Hajduk, 1993; Pilch \& Bauman, 2001, pp. 39-42).

In the author's own research, ethnographic observation was carried out, which comprised four stages:

- $\quad$ the first (descriptive observation) aimed at recognizing the area of research exploration, as well as learners and teachers from classes I-III and IV-VI;

- the second (focused observation) involved the registration (due to the prepared observation guides) of all children's behaviour patterns (both verbal and non-verbal) within cultural experience;

- the third (selective observation) enabled the verification of formulated conclusions and the detailed registration of children's behaviour patterns which suggest their adaptation to the new life and learning environment in which the norms, values and behaviour models (demanded by the foreign country's culture) are acquired;

- the fourth (self-observation) made use of the principle of reflectiveness, due to which what was subjected to observation was both the researcher and the process of her own assimilation (the acceptance of the cognitive perspective present in a particular field of study) (Konarzewski, 2000, pp. 113-114). 
Ethnographic observation was complemented by a cultural interview containing questions which enable (a) achieving the full picture of the child's functioning in particular areas of life, (b) specifying the feeling of identity (including national one), (c) diagnosing the degree of identification with groups which the child contacts, (d) specifying the degree of acculturation, with regard to the competence sphere - the knowledge and understanding of behaviour patterns - and the emotional sphere - both the personal attitude to different events which children observe and in which they take part, and the evaluation of behaviour (Chodynicka \& Więckowska, 2005, pp. 370-394). The interview also comprised parents' questionnaires, which aimed at learning different forms of children's non-school activities and at eliciting opinions on the ethnic and cultural specificity of the borderland and the transmission of cultural heritage which takes place there.

The studies in the Polish-German borderland have been conducted three times:

- $\quad$ in 2004 - the surveyed Polish children and their German peers attended classes I-III;

- $\quad$ in 2007 - these learners continued education in classes IV-VI;

- $\quad$ in 2017 - the research was repeated among I-III class learners.

Altogether in the studies in 2004, 2007, and 2017, 160 learners from the Primary School in Gubin have been surveyed - 80 children from Poland (41 girls and 39 boys) and their 80 peers from Germany (40 girls and 40 boys). 52 parents (43 women and 9 men) from Poland have taken part in the studies as well.

\section{THE CHARACTERISTICS OF THE INVESTIGATED BORDERLAND}

The undertaken discussion on the culturalization of Polish learners in German school requires a broader view on the specificity of historical and sociocultural determinants of the Polish-German borderland in South-Eastern Poland. Referring to the previously mentioned Lewowicki's concept, the elements of the theory of identity behaviours were used to characterize, describe and explain various manifestations of the activity of borderland people. In the distinguished fields, these elements helped to specify selected basic determinants: 
- $\quad$ historical - presenting the historical fate of borderland communities, their identification with the territory and social group, and their nationality structure;

- $\quad$ sociocultural - characterizing the uniqueness of borderland culture, language and religion, as well as school education and institutions (organizations) which support culture;

- cultural-personal - constituting an imagined picture of "unlikeness", of specific qualities of groups and a description of the functioning stereotypes (typical ways of perceiving the Own and the Alien);

- economic - describing the living standards of minority and majority groups in borderlands, their civilizational position, technological condition, and life plans (Lewowicki, 1995a, pp. 51-63).

The historical determinants of the Polish-German borderland have been of crucial significance for the shaping (among its communities) of a particular view and diverse social attitudes to culture, language, religion and education. Many centuries of historical belonging of Western territories to the circle of German culture has largely determined the feeling of national awareness of their inhabitants and the high position of the German culture and language, which are important indicators of national identity. The assimilation processes, especially those taking place in the $19^{\text {th }}$ and early $20^{\text {th }}$ centuries, enhanced the disappearance of indigenous values of the Polish community's culture, which marked the beginning of a series of deculturalizing transformations - finally leading to this group's partial loss of cultural separateness and to including it into the dominating German cultural system (Poser-Zieliński, 1999, p. 51; Jurkowicz, 2014, pp. 1-10). The intense attempts at the Germanization of social life, which met strong opposition among ethnically Polish population but were supported by school education, as well as the process of rebirth of the Polish state and Poles' feeling of national identity resulted in evident transformations in the ethnic and language awareness of borderland residents. These changes brought about partial modification of the cultural system in the interwar period.

In the post-war years of the $20^{\text {th }}$ century, the shaping of cultural and regional identity of Poles and Germans inhabiting the borderland was mostly associated with the "open" or "closed" character of the border and the resulting possibility of cultural confrontation. Such confrontation either enhances gradual breaking with mutual prejudice and negative stereotypes or intensifies isolation in cultural contacts. What seemed to be shaped in the periods in which the Polish and German cultures permeated was the awareness (especially among Poles) of the need for 
acquiring particular language competences (both in German and in Polish) which would enable intercultural communication and gradual transition from the relation We-They to the relation We-You. This process gained an open and palpable character in the new cultural conditions after 1989. However, this particularly concerns the young generation of Poles and Germans.

The forming of cultural identity of both Polish and German population in the Western borderland have been always facilitated by educational activities. The historical development and the current condition of school education in this area has been widely explored in expert literature. For many years, regular studies have been conducted in this field also by researchers from Tadeusz Kotarbiński's Pedagogical College in Zielona Góra (since 2001 - the University of Zielona Góra) and Cottbus Pedagogical Institute of the University of Potsdam, or Humboldt University in Berlin (Jakowicka \& Mende, 1994; Gołdyka, 2013; Miłosz-Augustowska, 2015, pp. 1-23).

The results of this research, enriched with some studies in the field of educational history, social pedagogy and sociology, make it possible to specify current educational chances of children, youth and university students inhabiting the Western borderland. The authorial research was conducted in two borderland towns: Gubin - on the Polish side, and Guben - on the German, which in 1991 signed a bilateral agreement on collaboration. This contract was the first partnership agreement ${ }^{2}$ in the Polish-German borderland between the towns divided after World War II. It also became a showcase of a Eurotown and was awarded in 1996 the "European Medal”, and in 1997 - the "European Diploma” by the Council of Europe in Strasbourg. The collaboration of schools and educational institutions in both towns is considered the best in the whole Polish-German borderland. It comprises, e.g., educating Polish youth in Guben, learning the German language, cultural and sport contacts, exchange of pedagogical experience among teachers (Guz-Vetter, 2002, pp. 106-110). Primary school learners in the whole Polish-German borderland are taking part in the project "Uczę się Twojego języka [I am learning your language]”. It entails voluntary learning the German language as an extracurricular activity in classes I-III and as an optional subject in classes IV-VI, as well as learning within the educational programme "Tolerancyjna Brandenburgia [Tolerant Brandenburg]” (Adamski, 1998, pp. 53-68; Lisiecki, 1999, pp. 487-494).

2 The partnership agreement between Gubin (Poland) and the towns Laatzen and Guben (Germany) was signed on the January 19, 1991. It specified the general aims of collaboration and detailed goals were to be specified annually in separate documents. Quoted in: Osękowski \& Szczegóła, 1999, p. 333. 
In compliance with the Act on ratification of the framework convention on the protection of national minorities, enacted on the April 27, 2000 by the Polish Parliament, the German minority is included into educational activities as well. As regards cultural collaboration, it is of crucial significance and comprises the activity of institutions (organizations) and associations. The educational process of both Polish and German children is supported by the steadily developing cultural cooperation conducted by Gubin Cultural Centre and the Centre for Culture in Guben. The joint animation activities focus on the organization of the following artistic events: "Wiosna nad Nysą [Spring by the Nysa River]" (taking place annually since 1961), International Plain-air Fine Arts (since 1993), International Plainair Arts, the annual review of the groups taking part in the International Folklore Festival in Zielona Góra and in the Polish-German cultural workshops. They all enable direct contacts between Poles and Germans, familiarization with the common cultural heritage, and - as a result - a change in the existing stereotypes.

In the aspect of perceiving one's own unlikeness and belonging, the analysis of many studies (in the field of psychology, sociology and social pedagogy) which concern shaping the social identity of the inhabitants of the Polish-German borderland allows for characterizing the stereotypes of a Pole and a German, which function in the awareness of both groups on the basis of occasional contacts (identifications based on similarities-dissimilarities) or relatively permanent ones (identifications based on belonging-not belonging) (Kaczmarek, 1997, pp. 153-158; Mucha, 1999, pp. 228-250; Sakson, 2011). They constitute an integral component of the feeling of national identity and they express the system of cognitive-emotional references which are crucial for the lasting of a particular community. What nowadays seems to be a characteristic feature of Poles' attitude to Germans and the German state is the phenomenon of ambivalence, understood as co-occurrence of opinions and attitudes which are substantially incoherent. Poles living in the borderland on one hand express their hope associated with the German neighbourhood or expect numerous threats due to this, but on the other hand - they neither believe in forming friendly relationships nor notice the potential development of partner relationships. This lasting social distance and unsure, expecting attitudes of Poles to Germans can be justified by the functioning - in this cultural area - of the German "complex" or "syndrome”, resulting from historical antagonisms projected onto the present time or the future and from the fear of increasing the civilizational distance to "the West" in the economic level and welfare (Kurzępa, 1996, pp. 149-160; Sakson, 1996, pp. 29-38; Makaro, 2016, pp. 205-221).

In the opinions of young Poles, the image of a German and the German community is currently shaped by frequent, personal contacts with German peers, 
which enhance the development of more positive (friendly) mutual attitudes. The Polish youth perceives a German in both positive categories: hardworking, reliable, disciplined, obedient, thrifty, caring for order and efficiently managing home budget, as well as negative categories: conceited, showing superiority, over-ambitious, insensitive, too loyal and servile. These evaluations express the ambivalent attitude to German neighbours, revealing its incoherent or even contradictory character. The attitudes of Germans to Poles mostly express the negative mindset concerning the Polish community, the major feature of which is the unwillingness resulting from both historically rooted prejudice in the Polish-German borderland and the widespread (in Germany) ignorance concerning Poland. Despite the close neighbourhood of both countries, the typical negative qualities attributed to the Polish community - messiness, primitivism, laziness, alcohol abuse, quarrelsomeness, intolerance, instability of views, lack of organizational skills - only slightly enable the modification of such firmly rooted stereotypes and mutual relations (Swadźba, 1997, pp. 67-77; Szarota, 1996). Therefore, it seems that the shaping of a new cultural, social and economic order both in Poland and Germany may be of crucial significance for acquiring the new quality of the feeling of national and regional identity of borderline inhabitants and might bring about a chance for starting the process of gradual breaking the negative prejudices and stereotypes towards each other.

The development of the economic condition of the Polish-German borderland, especially after 1990, specified the quality of its inhabitants' life and was determined by many political and social factors, such as: historical culture-creating processes, the effects of war and decapitalization of material wealth in Western territories in the first years after the war, the "temporariness" of the attitude of the population resettled there to houses and farms taken over from Germans, and the functions and specific (strongly formalized - dividing or weakly formalized) character of the Polish-German border until 1990 (Koćwin, 1993; Ciok, 2004). The occurring changes as well as the shaping both in Poland and in Germany of the new socio-political reality in the 1990s intensified the restructuring of industry and increased economic potential on both sides of the border. However, those changes contributed to the processes of social disintegration, resulting - among other things - from increased borderland mobility, unfavourable demographic processes due to emigration of the young, the feeling of unemployment threat, or lack of the feeling of self-effectiveness in the matters important to local communities (Kurcz, 2011, pp. 83-94).

Today, these problems are also palpable among borderland residents and they enhance social pathology as well as the relativism of Poles in evaluation of these 
phenomena. In the sub-region of Zielona Góra, where the studies were conducted, a specific type of the so called middle class came into being as a result of this. It comprises many owners of various minor firms, dealing, for example, with the sale of German goods, street market trade or car services for German clients, which are aimed at quick, often illegal profits. These phenomena have already been frequently analysed in expert literature (Podgórecki, 1995; Kurzępa, 2007; Urbaniak, 2017, pp. 129-137).

Four Euroregions (created within the Phare programme) function in the territories of the Polish-German borderland: "Neisse-Nisa-Nysa" (1991), "SzprewaNysa-Bóbr / Spree-Neisse-Bober” (1993), "Pro Europa Viadrina” (1993), and "Pomerania” (1995). The Euroregion “Szprewa-Nysa-Bóbr / Spree-Neisse-Bober”, to which the bordering towns Gubin and Guben belong, comprises 19 towns and communes situated within the triangle Gubin-Zielona Góra-Żary on the Polish side and two communes and the town Cottbus in Germany (Kwiatkowski, 1997, pp. 83-84). The tasks and goals of the Euroregion have been divided into four groups of problems: (a) economy, transport, communication and tourism, (b) agriculture, forestry and environmental protection, (c) education, culture, sport and movement, (d) information and social communication. Among the joint educational activities, special significance should be attributed to trans-border school education, which reaches the largest scale at the level of secondary and vocational schools. After completing class II of general secondary school, learners from Polish secondary schools can continue their three-years-long education in German school (Gesamtschule) in Guben and pass their final exams (which are recognized both in Germany and Poland). The graduates of this school can undertake the course German Studies (without entrance exams) in the European University "Viadrina" in Frankfurt on the Oder, or the University of Wrocław (Trzop, 1999, pp. 526-527). One of the goals of the Euroregion's activity is the widely understood promotion of Polish and German culture, aimed at developing the common cultural heritage of borderland communities. With no doubt, the further economic collaboration conducted in the Polish-German borderland will shape a particular type and character of mutual contacts and cultural behaviour patterns.

The presented description of continuity and change in cultural processes taking place in the Polish-German borderland makes it possible to specify its typical qualities. According to Grzegorz Babiński's concept, many of them are also characteristic features of the so called new borderland (Babiński, 2001, pp. 20-30). This borderland is of contact nature (in the territorial and cultural sense). Moreover, its characteristic features are high social, cultural and economic diversification, civilizational distance, clearly horizontal perception of intercultural relations and the 
lack of well-consolidated full social stratification. This character has influence on the occurring culturalization processes, which are often determined by the lack of cultural competences of borderland inhabitants, especially the competences concerning daily life and social interactions.

\section{THE PROCESS OF CULTURALIZATION OF POLISH LEARNERS IN GERMAN SCHOOL - RESEARCH RESULTS}

\section{FEELING OF IDENTITY}

On the basis of the conducted studies and analyses, three basic levels of learners' feeling of identity were distinguished in the area of: the "I" condition, the concept of oneself in the world, and the possible contact with the world:

- low (minimized feeling) - characterized by the orientation rather towards the surrounding, real world (things, subjects, phenomena) than towards experiencing oneself and the relations with Others;

- medium - consisting in perceiving oneself as the subject with the simultaneous feeling of self-effectiveness (the belief in one's ability to influence the surrounding and other people),

- $\quad$ high - comprising the fulfillment of all three fields of identity feeling: $I, I$ - the world, and I-Others.

In the "I" dimension, Polish children still have a high level of the feeling of "I". On one hand, it is formed through appreciated religious values (in contrast to their German peers) as well as lay, vital or hedonistic truths. Yet, on the other, this feeling is most frequently referred to individualistic behavior and the preferences of the peer group.

Placing themselves in the world ( $\mathrm{I}$ - the world), all surveyed children declare the willingness to familiarize with the world and the problem-free life full of changes and adventures. However, they are unable to understand the world in which they live and they do not want to undertake activities aimed at its change (rebuilding). The medium level of the feeling of identity and self-effectiveness of all learners in this dimension is surely related to the threats from the world which they experience (they indicated terrorist attacks, wars, excessive bad politics, etc.) and the unfulfilled need for the feeling of their own safety, which is very important at that age. 
As regards social functioning (I - Others), children view their potentialities differently, achieving in this sphere the highest level of the feeling of identity and self-effectiveness. Learners want to experience Others directly, to get acquainted with them, to accept their uniqueness and/or unlikeness. Children clearly distinguish between "I" and Others, the dominating form of social bonds is the instrumental relation and the undertaking (on their own initiative) such activities that can bring measurable benefits to "I". In their social functioning, learners are more often guided by the opinions of their peers than of adults.

The surveyed children's level of the feeling of identity is differentiated not only in regard to its scope (size) and cultural determinants, but also in regard to respondents' age. Younger learners (classes I-III) have a medium level of the feeling of identity, which increases with age and in upper classes reaches a high level. It can be supposed that what takes place in this period - due to the development and integration of learners' cognitive and experiential functions, as well as their reaching a stable level of school maturity - is the reorganization of the own person and of the self-image, which leads to the well-balanced development of the feeling of identity, bonds with others and self-fulfilment. Children can also specify their identity in the context of criterial and correlative attributes and they manifest the feeling of this identity and social behaviour related to it. In the perception of oneself and others, some particularly positively tinted information about oneself is visible, which confirms the advantage of increasing self-esteem (self-valorization) over the understanding, acceptance and need for protection and positivity of the self-image (Brycz, 2004, pp. 50-69). This bias in viewing oneself and others seems typical of the period of medium childhood and fulfils an important regulatory function through the stimulation of activeness and development.

\section{NATIONAL IDENTIFICATIONS}

The undertaken studies also involved an attempt at recognizing and specifying learners' national identifications, which constituted a specific "conglomeration of objective (observable from outside) qualities of individuals' behaviour patterns and acts of their consciousness, their self-identifications as members of particular cultural community" (Kłoskowska, 1992, p. 7). It was simultaneously assumed that children could present various intensity of national identity, which reflects: weak feeling of national identity (Polish identity is weaker than German or the opposite), well-balanced mixed feeling (no dominant identity - I feel equally Polish and German), strong feeling (the domination of homogeneous Polish or German identity). Moreover, the differentiated intensity of the feeling of national identification reflects identity-alienation behaviour patterns. 
The contact character of the Polish-German borderland unambiguously determines national identifications of children in Guben and contributes to a change in the feeling of identity of their peers of other nationality than German. What dominates among the surveyed children from Poland is the homogeneous German identity, which at the same time means strong identification with the majority's national culture (cf. Figure 2). Only 20\% of learners (year 2004), 6\% (2007), and 9\% (2017) declare the category of balanced mixed identity (I feel a Pole and a German to the same extent), and $2-3 \%$ of children identify with Poland as their homeland.

Figure 2. Examined Children's Declarations of National Identification

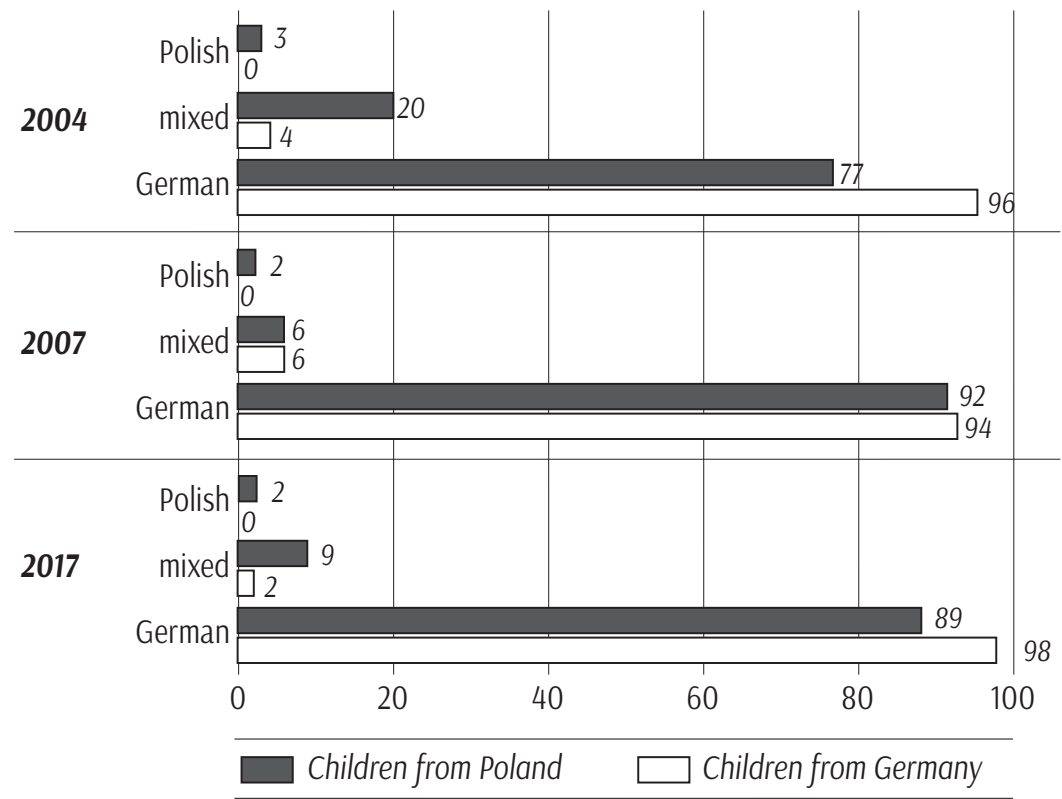

Source: author's own research.

The interviews conducted with these learners also confirm the frequent occurrence of lack of identification both with the own ethnic minority group and the dominating German national culture. Yet, despite the feeling of specific alienation, the respondents' final declarations move towards the latter. Thus, Polish children consider themselves to be Germans and they declare the feeling of German national identity. This is undoubtedly supported by the educational system (at school children learn and familiarize with the German language and culture, take part in the activities of German cultural and educational institutions outside 
school) as well as the high economic status of the majority group. Most frequently, they also associate their life and educational plans with Germany, where their parents see more chances for a "better" life than in Poland.

The Polish learners do not want to be distinguished in the school and peer environment due to their ethnic origin, which is confirmed by the observation of their behaviour. Therefore, they often experience strong enculturation stress, which enhances the feeling of alienation and triggers off the identity conflict (particularly in the sphere of axiological preferences and norms). Learners' identification with the national culture of the majority points to the occurring changes in their criterial and correlative identity attributes which are determined by other factors than family socialization and culturalization.

\section{CULTURALIZATION STRATEGIES}

What has been taken into account while characterizing the patterns of respondents' adjustment to functioning in the environment different from their original culture are some selected components of the cultural model of acquiring biculturalism, elaborated by Boski:

- declared feeling of ethnic (of the country of origin) and/or national (of the country where education takes place) identity;

- command and use of languages (of both countries);

- $\quad$ social contacts (with the members of the ethnic and majority group);

- family and school duties (in the ethnic and majority group);

- $\quad$ granted rights (in the ethnic and majority group) (Boski, 2009, pp. 540-550).

The respondents' declarations subjected to statistical cluster analysis allowed for distinguishing four profiles of the applied culturalization strategies:

- $\quad$ integration profile - manifested in a positive attitude and willingness to maintain the own cultural heritage, openness, and participation in the life of the majority community, as well as in mutually balanced levels of ethnic and national indicators pertaining to identity, the command and use of languages, social contacts, duties and rights. For an individual, this is the most beneficial strategy, though it is hard to achieve, requires cognitive and emotional effort, and motivation;

- $\quad$ ethnic profile - evident preference of the own ethnic group in the field of identity, language and social contacts, a well-balanced level of the own duties and rights. The relations with the majority group are limited to the necessary 
minimum and negative emotions prevail in them. The receiving culture is viewed from outside, the individual is rather an observer than a participant. The mutual lack of understanding and will to contact is a characteristic feature, an effect of which is withdrawal and unwillingness;

- national profile - consent for participation in the culture of the majority and resignation from maintaining the cultural identity presented so far. It is most often associated with the unwillingness to the ethnic culture, its negative evaluation, not using the language, sometimes conscious disclaiming one's origin. The main source of satisfaction and positive emotions are the relations with the members of the majority group. The individual tends to self-fulfilment and achieving aims in a new environment - behaviour, clothes, speech become similar to the ones presented by the peers from the receiving group, the level of recognizing family and school duties is low;

- dispersed - cutting off and lack of participation in both the original culture and in the mainstream of the receiving culture. It is often manifested in dysfunctional behaviour (e.g., health problems) and is associated with the distance between the original and receiving culture, which the individual strongly experiences (Boski, 2009, pp. 540-550).

The comparison of the empirical data obtained in the 2004, 2007, and 2017 makes it possible to state that - in the case of learners from Poland - cultural changes have the processual course, which results in the following characteristics:

- $\quad$ the overall change comprises the symbolic sphere (feeling of identity, language), social structure (peer contacts), and the sphere of economic behaviour (living standards);

- $\quad$ the change has a rapid course and takes place in the perspective of one generation;

- $\quad$ it has specific stages (from the confrontation of cultures, through the adaptation of new cultural contents, to deculturation - taking over the patterns of the alien culture);

- $\quad$ it causes multiplied shifting of the border of what is own - strangeness, familiarized strangeness;

- it has specific consequences.

This process results in (a) assimilation - associated with limited contacts with the people coming from the own culture, with unwillingness towards the original culture, its negative evaluation, not using the language, sometimes conscious 
disclaiming the own origin, as well as with drawing satisfaction and positive emotions from the relations with the members of the receiving culture; or (b) separation - consisting in minimal contacts with the majority, negative emotions prevailing in them, learners' perception of the receiving culture from outside (more as observers than participants), mutual lack of understanding and will to contact, resulting in withdrawal and unwillingness.

The presented considerations do not reflect the full image of culturalization processes to which Polish children learning in German schools are subjected. The discussion can only allow for an attempt at capturing, describing and interpreting their characteristic features and tendencies, which are of substantial significance for undertaking particular educational activities in multicultural societies.

The surveyed learners' communities present culturalization strategies which have differentiated profiles, mostly the national and dispersed one. Referring to the earlier mentioned concepts - Lewowicki's theory of identity behaviours and Boski's cultural theory of acquiring biculturalism - the applied strategies and the identity behaviours manifested within them point to the undergoing changes in the image of particular fields (components) of cultural identity of the young. For most learners, this identity has homogeneous character and does not combine ethnic identification (with the original country) with the culture in which they are educated. The presented reflections necessitate formulating new questions in the context of theory and practice of intercultural education, making it possible to familiarize with the new sociocultural reality in which the contemporary Polish child lives.

\section{References}

Adamski, F. (1998). Potencjał społeczno-kulturalny pogranicza południowo-zachodniej Polski (na przykładzie województwa jeleniogórskiego i zielonogórskiego). In: Z. Jasiński, T. Lewowicki \& J. Nikitorowicz (Eds.), Potencjał społeczno-kulturowy polskich pograniczy (pp. 53-68). Opole: Opolska Oficyna Wydawnicza.

Babiński, G. (2001). Lokalność - pogranicza - globalizacja. Refleksje nad kierunkami badań nad współczesnymi problemami pogranicz narodowych. In: J. Leszkowicz-Baczyński (Ed.), Transgraniczność w perspektywie socjologicznej. Kontynuacje i wyzwania (pp. 20-30). Zielona Góra: Lubuskie Towarzystwo Naukowe.

Berry, J.W. (1994). Acculturative Stress. In: W.J. Lonner \& R.S. Malpass (Eds.), Psychology and Culture (pp. 211-215). Boston: Allyn and Bacon.

Boski, P. (1992). W stronę modelu teoretycznego tożsamości: wymiary tożsamości narodowej. In: P. Boski, M. Jarymowicz \& H. Malewska-Peyre, Tożsamość a odmienność kulturowa (pp. 86-108). Warszawa: Instytut Psychologii PAN. 
Boski, P. (2009). Kulturowe ramy zachowań społecznych. Podręcznik psychologii międzykulturowej. Warszawa: PWN.

Brycz, H. (2004). Trafność spostrzegania własnych i cudzych zachowań. Kraków: Oficyna Wydawnicza „Impuls”.

Chodynicka, A.M., \& Więckowska, J. (2005). Wywiad kulturowy. In: K. Stemplewska-Żakowicz \& K. Krejtz (Eds.), Wywiad psychologiczny. Vol. 3. Wywiad w różnych kontekstach praktycznych (pp. 370-394). Warszawa: Pracownia Testów Psychologicznych Polskiego Towarzystwa Psychologicznego.

Ciok, S. (2004). Pogranicze polsko-niemieckie: problemy współpracy transgranicznej. Wrocław: UW.

Frankfort-Nachmias, Ch., \& Nachmias, D. (2001). Metody badawcze w naukach społecznych. Poznań: Zysk i S-ka.

Gołdyka, L. (2013). Pogranicze polsko-niemieckie jako przestrzeń socjalizacji. Warszawa: Wydawnictwo Naukowe „Scholar”.

Guz-Vetter, M. (2002). Polsko-niemieckie pogranicze. Szanse i zagrożenia w perspektywie przystapienia do Unii Europejskiej. Warszawa: ISP.

Hajduk, E. (Ed.) (1993). Metoda panelu: różne aplikacje. Zielona Góra: WSP.

Hewstone, M. (1999). Kontakt i kategoryzacja: zmiana stosunków międzygrupowych w ujęciu psychologii społecznej. In: C.N. Macrae, Ch. Stangor \& M. Hewstone, Stereotypy i uprzedzenia. Najnowsze ujęcie (pp. 263-295). Gdańsk: GWP.

Jakowicka, M., \& Mende, K.D. (Eds.) (1994). Edukacja w okresie przemian ustrojowych. Zielona Góra - Cottbus: WSP.

Jurkowicz, B. (2014). Polsko-niemieckie pogranicze. Historia i teraźniejszość. FAE Policy Paper, 6, pp. 1-10.

Kaczmarek, U. (1997). Determinanty tożsamości na pograniczu polsko-niemieckim. In: Z. Jasiński, \& A. Kozłowska (Eds.), Tożsamość narodowa młodzieży na pograniczach (pp. 153-158). Opole: UO.

Kłoskowska, A. (1992). Konwersja narodowa i narodowe kultury: studium przypadku. Kultura i Społeczeństwo, 36(4), pp. 3-32.

Koćwin, L. (1993). Polityczne determinanty polsko-wschodnioniemieckich stosunków przygranicznych 1949-1990. Wrocław: UW.

Konarzewski, K. (2000). Jak uprawiać badania oświatowe. Metodologia praktyczna. Warszawa: WSiP.

Köpp, I., \& Lippitz, W. (2001). Praktyka badań jakościowych prowadzonych z dziećmi. In: D. Urbaniak-Zając, \& J. Piekarski (Eds.), Jakościowe orientacje w badaniach pedagogicznych. Studia i materiały (pp. 158-160). Łódź: UŁ.

Kurcz, Z. (2011). Z pogranicza na pogranicze..., z pogranicza na transgranicze... i z powrotem? Kierunki i charakter przemian na polskich pograniczach. In: Z. Kurcz (Ed.), Polskie pogranicza w procesie przemian. Vol. 2 (pp. 83-94). Wałbrzych: WWSZiP.

Kurzępa, J. (1996). Tolerancja pogranicza - pogranicze tolerancji. Rocznik Lubuski, 22(2), pp. 149-160.

Kurzępa, J. (2007). Socjopatologia pogranicza: zmiany w życiu społeczności zachodniego pogranicza. Studium socjologiczne. Zielona Góra: UZ. 
Kvale, S. (2004). InterViews. Wprowadzenie do jakościowego wywiadu badawczego. Białystok: Wydawnictwo Uniwersyteckie „Trans Humana”.

Kwiatkowski, J. (1997). Komplementarność miast granicznych jako problem polityki, kształtowania przestrzeni i socjologii. In: L. Gołdyka, J. Leszkowicz-Baczyński, L. Szczegóła \& M. Zielińska (Eds.), Transgraniczność w perspektywie socjologicznej (pp. 79-101). Zielona Góra: Lubuskie Towarzystwo Naukowe, WSP w Zielonej Górze.

Lewowicki, T. (1995a). Problemy tożsamości narodowej - w poszukiwaniu sposobów uogólnionych ujęć kwestii poczucia tożsamości i zachowań z tym poczuciem związanych. In: M.M. Urlińska (Ed.), Edukacja a tożsamość etniczna (pp. 51-63). Toruń: UMK.

Lewowicki, T. (1995b). O badaniach społeczności pogranicza - od parcjalnych opisów ku elementom teorii zachowań tożsamościowych. In: J. Nikitorowicz (Ed.), Edukacja międzykulturowa - w kręgu potrzeb, oczekiwań i stereotypów (pp. 13-26). Białystok: Wydawnictwo Uniwersyteckie "Trans Humana".

Lisiecki, S. (1999). Euromiasto Gubin-Guben. Problem niemieckiego dziedzictwa kulturowego. In: L. Gołdyka (Ed.), Transgraniczność w perspektywie socjologicznej - kontynuacje (pp. 487-494). Zielona Góra: Lubuskie Towarzystwo Naukowe.

Makaro, J. (2016). Pogranicze polsko-niemieckie w refleksji socjologicznej z perspektywy ćwierćwiecza. Pogranicze. Studia Społeczne, 27(2), pp. 205-221. DOI: 10.15290/ pss.2016.28.02.11.

Miles, M.B., \& Huberman A.M. (2000). Analiza danych jakościowych. Białystok: Wydawnictwo Uniwersyteckie „Trans Humana”.

Miłosz-Augustowska, J. (2015). Współpraca polsko-niemiecka na pograniczu po 25 latach. Perspektywy dla powstania nowego rodzaju partnerstwa. Biuletyn Niemiecki, 60, pp. 1-23.

Moustakas, C. (2001). Fenomenologiczne metody badań. Białystok: Wydawnictwo Uniwersyteckie „Trans Humana”.

Mucha, J. (1999). Polska kultura narodowa jako kultura własna i jako kultura obca. Podsumowanie. In: J. Mucha (Ed.), Kultura dominująca jako kultura obca. Mniejszości kulturowe a grupa dominujqca w Polsce (pp. 228-250). Warszawa: Oficyna Naukowa.

Ogrodzka-Mazur, E. (2007). Kompetencja aksjologiczna dzieci w młodszym wieku szkolnym. Studium porównawcze środowisk zróżnicowanych kulturowo. Katowice: UŚ.

Ogrodzka-Mazur, E. (2010). Experiencing the Acculturation Stress by Polish Children in German Schools: Between Integration and Marginalization. The New Educational Review, 20(1), pp. 17-28.

Osękowski, Cz., \& Szczegóła, H. (1999). Pogranicze polsko-niemieckie w okresie transformacji (1989-1997). Zielona Góra: WSP.

Pilch, T., \& Bauman, T. (2001). Zasady badań pedagogicznych. Podejście ilościowe i jakościowe. Warszawa: Wydawnictwo Akademickie „Żak”.

Podgórecki, A. (1995). Społeczeństwo polskie. Rzeszów: WSP.

Poser-Zieliński, A. (1999). Akulturacja i asymilacja - dwie strony procesu etnicznej zmiany w ujęciu antropologii i etnohistorii. In: W. Molik \& R. Traba (Eds.), Procesy akulturacji/asymilacji na pograniczu polsko-niemieckim w XIX i XX wieku (pp. 43-64). Poznań: UAM.

Sakson, A. (1996). Naród niemiecki w świadomości społecznej Polaków. Życie i Myśl, 3, pp. 29-38. 
Sakson, A. (2011). Przemiany tożsamości lokalnej i regionalnej mieszkańców Ziem Zachodnich i Północnych. In: A. Michalak, A. Sakson \& Ż. Stasieniuk (Eds.), Polskie Ziemie Zachodnie. Studia socjologiczne (pp. 79-100). Poznań: Instytut Zachodni.

Stephan, W.G., \& Stephan, C.W. (1999). Wywieranie wpływu przez grupy. Psychologia relacji. Gdańsk: GWP.

Swadźba, U. (1997). Identyfikacje narodowe a postawy wobec Niemców. In: M. Dziewierski, \& T. Nawrocki (Eds.), Grupa etniczna - Region - Tożsamość kulturowa (pp. 67-77). Katowice: UŚ.

Szarota, T. (1996). Niemcy i Polacy: wzajemne postrzegania i stereotypy. Warszawa: PWN.

Trzop, B. (1999). Transgraniczna współpraca regionalna - Euroregion Sprewa - Nysa - Bóbr. In: L. Gołdyka (Ed.), Transgraniczność w perspektywie socjologicznej - kontynuacje (pp. 523-533). Zielona Góra: Lubuskie Towarzystwo Naukowe.

Urbaniak, P. (2017). Patologia pogranicza polsko-niemieckiego na kartach reportaży Włodzimierza Nowaka w socjologicznej perspektywie. Naukowy Przegląd Dziennikarski, 3, pp. 129-137.

Wrzesiński, W. (Ed.) (1993). Wokół stereotypów Niemców i Polaków. Wrocław: UW.

Wysocka, E. (2003). Akulturacja. In: T. Pilch (Ed.), Encyklopedia pedagogiczna XXI wieku. Vol. 1 (pp. 74-79). Warszawa: Wydawnictwo Akademickie „Żak”. 